\title{
Article
}

\section{The Anti-social Behaviour, Crime and Policing Act 2014: implications for sex workers and their clients}

\author{
Kingston, Sarah and Thomas, Terry \\ Available at http://clok.uclan.ac.uk/31283/ \\ Kingston, Sarah ORCID: 0000-0002-9226-1915 and Thomas, Terry (2017) The \\ Anti-social Behaviour, Crime and Policing Act 2014: implications for sex \\ workers and their clients. Policing and Society: An International Journal of \\ Research and Policy, 27 (5). pp. 465-479. ISSN 1043-9463
}

It is advisable to refer to the publisher's version if you intend to cite from the work. http://dx.doi.org/10.1080/10439463.2015.1072181

For more information about UCLan's research in this area go to http://www.uclan.ac.uk/researchgroups/ and search for <name of research Group>.

For information about Research generally at UCLan please go to http://www.uclan.ac.uk/research/

All outputs in CLoK are protected by Intellectual Property Rights law, including Copyright law. Copyright, IPR and Moral Rights for the works on this site are retained by the individual authors and/or other copyright owners. Terms and conditions for use of this material are defined in the policies page.

\section{CLoK}

Central Lancashire online Knowledge www.clok.uclan.ac.uk

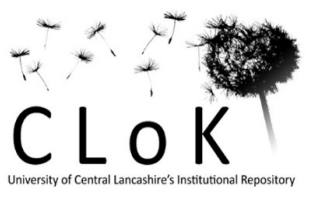


The Anti-social Behaviour, Crime and Policing Act 2014: implications for sex workers and their clients

\begin{abstract}
The Anti-social Behaviour, Crime and Policing Act 2014 introduced new powers to deal with behaviour deemed to be "anti-social”. In this paper we consider how the new law could be used against sex workers and their clients and the impact this may have. Although the new powers were not intentionally designed to respond to prostitution, we suggest that they will be utilised to tackle it. We argue that the law will be used inconsistently in a way which will go directly against policy which seeks to 'tackle demand' and take a less punitive approach to dealing with sex workers. Despite a policy shift to see sex workers more as victims and less as offenders, we draw on existing evidence to demonstrate that the new ASBO law will be utilised to exclude street sex workers from public spaces. We claim that a degree of 'policy re-fraction' will occur when the new laws are implemented by practitioners.
\end{abstract}

Key words: The Anti-social Behaviour, Crime and Policing Act 2014, sex work, prostitution 


\section{The Anti-social Behaviour, Crime and Policing Act 2014: implications for sex workers and their clients}

\section{Introduction}

The Anti-social Behaviour, Crime and Policing Act 2014 which received its Royal Assent on 13 March 2014 and came into effect incrementally during 2015 in England and Wales, introduces new powers which are believed to be more wide reaching than earlier laws which tried to take on the problem of 'anti-social behaviour' (ASB). The new interventions are designed to be easier to utilise, require a much lower evidential threshold and cover a wider range of behaviours. This law has been introduced to respond to the 'thousands of people around the country ... still having their everyday lives blighted by anti-social behaviour' (Home Office 2012a).

In the first months of the former Conservative-Liberal Democrats coalition Government Home Secretary Theresa May had said the laws on anti-social behaviour needed changing: We need a complete change in emphasis, with people and communities working together to stop bad behaviour escalating...We need to make anti-social behaviour what it once was - abnormal and something to stand up to... rather than frequent and tolerated (cited in BBC News 2010)

The problems with the current system were seen to fall in its centralist 'top down' focus that did not engage the community sufficiently in tackling problems, and that was overly bureaucratic and complex; a degree of ‘stream-lining' was needed:

The mistake of the past was to think that Government could fix the problem with a 'one size fits all' model. It cannot. Anti-social behaviour is a fundamentally local issue, one that looks and feels different in every area, in every neighbourhood and to every victim. The answers lie in local agencies that respond to the needs of victims and communities. They should take the problem seriously, have the freedom to do what they know will make a difference, and have the right powers to act (Home Office 2012b: 3). 
The Anti-social Behaviour, Crime and Policing Bill’s introduction into the House of Commons on 9 May 2013 was therefore deemed as 'a welcome fulfilment of the positive obligation on the state to protect people against having their rights interfered with by others' (House of Lords/House of Commons 2013:3).

Yet concerns were quickly raised about the 'net-widening' potential of the proposed new powers. The campaign group Justice declared their disappointment with the current proposals because:

the government has not taken the opportunity in this Bill to conduct a comprehensive reform of the anti-social behaviour regime...there is a lack of imagination and innovation in the reforms and for the most part what has been proposed simply tinkers with labels, while framing the proposed orders to cover even wider categories of behaviour than the existing measures... (Justice, 2013:1)

Lord Macdonald QC and a former Director of Public Prosecutions said the proposals were extremely broad and could result in 'serious and unforeseeable interferences in individual rights to the greater public detriment' (cited in Bingham 2013:1). Liberty suggested:

This new [IPNA] power is breathtakingly wide... How many times a day do we cause nuisance and annoyance to others? Irritatingly noisy passersby? ... The test as it currently stands has allowed for a frighteningly broad range of behaviour to be brought within the scope of the ASBO regime. Indeed, the already wide definition of 'behaviour likely to cause, harassment, alarm or distress' is arguably one of the reasons that the orders have to date been so inappropriately and over used. Widening the definition yet further is only going to make grossly inappropriate use even more likely (Liberty 2013 (a):8).

The proposed Injunctions to Prevent Nuisance and Annoyance (IPNAs) were heavily scrutinised by the parliamentary Joint Committee on Human Rights in two reports. In its first report the Committee declared the 'definition of anti-social behaviour is broad and unclear' (House of Lords/House of Commons 2013: 3) and in the second that the definition should be made more precise and objective. They claimed that:

In our view, 'conduct capable of causing nuisance or annoyance to any person' is not a sufficiently precise definition to satisfy the requirement of legal certainty demanded by both the common law and human rights law, because it does not provide enough 
guidance to people, including children, as to what behaviour is expected of them to avoid the risk of an injunction. (House of Lords/House of Commons, 2014: para4)

The Lords amended the Bill by removing the test of 'capable of causing nuisance or annoyance to any person' from the Injunctions to Prevent Nuisance and Annoyance (IPNA) and renamed them as just Injunctions (Travis 2014). Concerns still remain about the broad reaching and net-widening potential of the new powers contained in the Act which we consider in this article, focusing specifically on 'prostitution'.

Although the new Act has not been explicitly designed to respond to prostitution, the fear is that it will, nonetheless, be used against street sex workers and their clients. This was observed when Anti-social Behaviour Orders (ASBOs) were initially introduced in 1998 when government guidance at that time did not indicate that ASBOs would be used to deal with prostitution (Hewitt, 2007; Jones \& Sagar, 2001), yet as commentators later observed sex workers were 'brought into the ambit of the ASBO by a side wind' (Sagar, 2007:155).

Support for utilising anti-social behaviour (ASB) law has previously been suggested by the All Party Parliamentary Group (APPG) on Prostitution and the Global Sex Trade. Following its 2014 inquiry into prostitution legislation the APPG recommended that soliciting offences be removed and ASB legislation be used to deal with 'persistent' anti-social behaviour (APPG 2014: 29). Although the APPG does not have legislative power, their views are deemed as symbolic of 'a neo-abolitionist trend that is spreading across Europe' which seeks to reduce supply and demand for prostitution through criminal law (Scoular \& Carline, 2014:609-10). Indeed, the Crown Prosecution Service, which also does not have legislative powers, but has a fundamental role in the implementation of current laws, has identified prosecution strategies of local police which include applying for an ASBO upon a fifth offence of soliciting or loitering (CPS, 2015: 1). Although police forces have been shown to use preventative measures to support women involved in prostitution in order to avoid the use of ASBOs, the police have also been known to prefer ASBOs to prosecuting under soliciting or kerb-crawling laws (Hubbard et al, 2008).

It is in this context that we suggest that these new powers will inevitably be used to tackle prostitution, particularly that taking place on the street, but fundamentally inconsistently across England and Wales. Our argument is that a degree of 'policy re-fraction' will occur as 
the police utilise the law in differential ways with street sex workers more likely to see this law being used against them. Although there have been recent moves to see sex workers more as victims whilst at the same time male clients have been increasingly problematised and criminalised, criminal sanctions against sex working persist. As Scoular and Carline (2014:613) argue 'there appears to be little political will in England and Wales to abolish offences relating to those who sell sex.' At the time of writing, some political support for decriminalisation has been documented by the English Collective of Prostitutes (ECP 2015) from their discussions with Members of Parliament, however it is still unclear whether any legal changes will occur with the election of the new conservative government in 2015.

In this paper we consider the first four Parts of the Act and argue that, as with criticisms raised with the introduction of ASBOs, the new measures introduced under the new law 'are not particularly innovative or new measures' (Phoenix, 2008:290). Instead, we suggest that they will offer a means for the criminal justice system to more easily target street sex workers. These more punitive and net widening powers add further support to claims of a 'harsher, deeper, targeted state-sponsored, coercive and punitive regulation of some of the most excluded, marginalised and impoverished individuals in prostitution' (ibid). We are also critical of the encouragement that these powers should be used to respond to 'local concerns', given that there are huge variations in how people from different towns, villages and cities perceive prostitution.

\section{Background to the Law on Anti-social Behaviour}

The term 'anti-social behaviour' first emerged in law in the Crime and Disorder Act 1998 and soon became an everyday part of the language. Anti-Social Behaviour Orders (ASBOs) had been proposed as the centre point of the new laws to combat this behaviour. These Orders were designed to combat behaviour not covered by criminal law, but which none-the-less causes 'alarm or distress'. Academic lawyers expressed their concern with what exactly this new category of behaviour was, lying somewhere between criminal activity and legal activity (Ashworth et al 1998) but everyone else was assumed to be able to know it when they saw it. Burney has carefully researched the origins of the ASBO and its beginnings within the realms of the management of social housing and noisy and disruptive tenants making life intolerable for their neighbours (Burney 1999; see also Field 2003). 
When ASBOs were introduced in 1998 there was never any stated intent to use them against on-street sex workers but having created this new category of behaviour named 'anti-social' it was not long before the link to street based sex workers was made. The Government declared that it was 'keenly aware of the nuisance and misery that prostitution can cause to local residents and businesses' (Home Office 2000:1) and went on to list a variety of, what it described as, 'prostitution related problems', including:

- Kerb-crawling and soliciting;

- Noise and harassment;

- Discarded needles and condoms;

- Thefts and muggings; drug related offences;

- Violence to women by pimps and clients; and

- Very serious offences such as rape and sexual exploitation of children

This list was repeated with a few extra items added (e.g. undermining economic regeneration) in the Home Office's 2003 A Guide to Anti-Social Behaviour Orders and Acceptable Behaviour Contracts (Home Office 2003:8), and in the 2004 consultation paper on prostitution (Home Office 2004: paras 2.17 and 7.4).

Thus the possibility of using ASBOs against sex workers had been quickly realised and: prostitutes are among the female recipients of ASBOs - not a class of person originally envisaged as falling within the anti-social behaviour remit, but along with beggars and increasingly 'moved on’ by the orders, especially where drugs are also involved (Burney 2005: 101)

The use of the ASBO laws to prohibit the behaviour of street sex workers was clarified in the definitive case of Chief Constable of Manchester v Potter [2003] EWHC 2272 (Admin). Lisa Potter was a sex worker in an area where it was said in court that:

the activities of street prostitutes had caused and were causing substantial problems to residents of, and lawful visitors to, that area. The problems were caused by activities of the prostitutes considered as a whole, not by those of the respondent or any other prostitute operating in the area considered on her own. 
The evidence in support of the application, which formed the basis of the Judge's findings, was given by two police officers and:

Much of it, by its very nature, hearsay, and some of it opinion, was, in summary, as follows. Most of the prostitutes frequenting the area did so in order to fund purchases of illegal drugs, mainly heroin and crack cocaine (Chief Constable of Manchester $v$ Potter [2003] EWHC 2272 (Admin) - Our emphasis)

The Potter case established that even if an individual street sex worker was not herself causing any 'harassment, alarm or distress' she was deemed to have contributed to the 'red light' character of a neighbourhood which - it was assumed - collectively did cause such feelings to the community, and therefore an ASBO was appropriate to prohibit her activities.

Interestingly, the police in Preston (where Ms Potter's ASBO was granted) quickly recognised the ineffectiveness of using ASBOs against street sex workers, because of their chaotic lifestyles and need to support their own and maybe another person's drug addiction (Kingston, 2004). As a result, the police adopted a strategy which allowed for an unofficial zone of tolerance in a non-residential part of the city whilst at the same time working in partnership with a support agency for sex workers (ibid).

Further doubts have been raised about the vague nature of police descriptions of a community being 'blighted' by sex workers, were highlighted later in another case in London. Police obtained an interim closure order on a brothel in Dean Street, Soho but when trying to confirm the Order in court their evidence of 'harm to the community' was questioned:

In court, Sergeant Dean Else argued that 'antisocial behaviour, crime and disorder, blatant acts of drug dealing and clipping in the local environs' were linked to the sale of sex inside 61 Dean Street.

When asked to provide examples of incidents of antisocial behaviour linked to the sex work flats he cited the example of a member of the public who had their wrist cut to facilitate a robbery at the premises. He admitted, however, that he had not been able to find any record of this incident on the police computer and Mr Justice Riddle said that the evidence was "third-hand, anonymous hearsay" (Taylor 2009 our emphasis). 
In contrast, evidence and testimonies from residents who lived nearby was put forward in the case which included testimony from the local rector (Dovkants 2009). He and another witness claimed that the brothel was crime-free and he had not observed anti-social activities taking place. The Judge refused to confirm the order and the brothel was re-opened (Taylor 2009). It would appear that in this case, only local police conceived this behaviour to be 'anti-social'.

The extent to which sex work could be said to be anti-social behaviour was yet further thrown in doubt by a report of the HM Inspectorate of Constabulary into the policing of anti-social behaviour. In their 2010 report Anti-social Behaviour: Stop the Rot they recorded that 'prostitution related activity' constituted $0 \%$ of the total incidents of anti-social behaviour for the two years 2008/9 and 2009/10 (HMIC 2010 Appendix A).

Thus a number of critics and commentators have raised serious doubts about the degree of 'anti-social behaviour' caused by sex work and the need, effectiveness and impact of the use of ASBO's against sex workers and their clients (Sagar, 2007). These concerns and criticisms are similarly applicable to the introduction of new measures under the Anti-social Behaviour, Crime and Policing Act 2014. It is with this new Act that we will now focus.

\section{Part 1 - Injunctions}

Injunctions to prevent nuisance and annoyance are now the new civil injunctions that will replace ASBOs. They will be available in the County Court for adults and in the Youth Court for 10 to 17-year-olds. The idea is that they will allow a wide range of agencies, including the police, local councils and social landlords to deal quickly with anti-social behaviour, nipping that behaviour in the bud before it escalates. Injunctions will replace not only the ASBO, but also the Anti-Social Behaviour Injunction (ASBI), the Individual Support Order for young people, the Drinking Banning Order and the Intervention Order for drug users.

The Act states that to obtain an Injunction:

The first condition is that the court is satisfied, on the balance of probabilities, that the respondent has engaged or threatens to engage in anti-social behaviour. The second condition is that the court considers it just and convenient to grant the injunction for the purpose of preventing the respondent from engaging in anti-social behaviour (Anti-Social Behaviour, Crime and Policing Act 2014 s1 our emphasis) 
The old law required that the activity had to have taken place whereas the new Injunction can be made if someone is only 'threatening' anti-social behaviour. The ASBO had to be 'necessary' to protect people from the behaviour in question, now it has only to be 'just and convenient'. The Association of Chief Officers of Police (ACPO) were critical of this change:

Similarly with the terminology 'just and convenient' where it was thought that this could be misinterpreted or misused, ACPO would advocate 'necessary' to replace this (ACPOs evidence to House of Commons 2013 Ev W 21para.10).

Furthermore, the need to prove the case to the civil standard of proof only will make the Injunctions easier to obtain; the need for an ASBO had to be proved at the higher criminal standard of proof as being 'beyond all reasonable doubt' (following the McCann case in 2002 $-R$ (on the application of McCann and others) v Crown Court at Manchester UKHL 39 [2002] 39). Whereas for Injunctions, only 'the balance of probabilities' is needed.

Although some have welcomed the lower standard of proof than previous legislation, several others have voiced their concerns. At the pre-legislative scrutiny stage of the Bill critics stated that this low-threshold test had the potential to 'bring a much wider range of behaviour under the umbrella of anti-social behaviour, potentially covering almost any kind of activity, potentially prompting disproportionate responses to very minor bad behaviour' (House of Commons 2013: Ev w21 para.22). Liberty raised further concerns that:

an applicant authority will have to provide much less evidence that an individual had engaged or threatened to engage in anti-social behaviour than is currently the case for an application for an ASBO ... The inclusion of hearsay evidence raises the possibility that the test could be met merely by the reported testimony of an absent individual (Liberty 2013b: 9)

This is somewhat worrying in the context of the disputes in Soho discussed above, where the police, despite non-support from local residents, sought to close down establishments they claimed were inciting anti-social behaviour. As the HMIC (2010:3) itself recognises the difficulty with the broad definition of what is 'anti-social' 'is the breadth of the term and the fact that it means different things to different people and organisations.' Thus, the interpretation of the law by the police and courts is open to local attitudes and discretion. 
When it comes to sex workers or prostitution related activities the question of who defines what is 'threatening' anti-social behaviour or whether someone is likely to or not to commit behaviour that needs to be prevented, is clearly open to debate. Previous research has demonstrated that attitudes towards prostitution are divided (Pitcher et al, 2006; Kingston 2013) and this has been duly recognised by the Home Office (2008) and the APPG (2014). Research has highlighted that the existence of prostitution, particularly on the street, has incited residential and business concerns, as a result of some of the potential 'anti-social' behaviours those involved engage in (Hubbard, 1998). Such 'anti-social' activities have included sex workers and their clients engaging in sex acts in car parks, people’s gardens and near schools (Kingston 2013). Other 'anti-social' activities could include discarding used condoms, syringes and general waste in places where people live and work.

Yet, research has also indicated that in some communities, residents and businesses have embraced and supported sex workers (Pitcher et al, 2006; Kingston, 2013). In Soho, for example, residents have been known to support sex workers in their neighbourhood and have expressed concerns for their safety (Dovkants 2009). Internationally, residents in Zurich, Switzerland have recently introduced drive in sex booths which are funded by local government, following a vote which supported their introduction (Associated Press 2013). This is all evidence that not all communities consider sex work to be 'anti-social' and that other communities seek to work with sex workers and their clients to better support them, whilst at the same time reducing the local 'anti-social' impact of prostitution, by for example dedicating specific areas as a space for prostitution. The application of these new powers is likely to vary from city to city, which raises questions about fairness and justice in this current system. Taking a more local and less top-down approach to dealing with behaviour considered to be 'anti-social' will therefore lead to wide variations in its implementation.

These differing perspectives are similarly observable in police practices. This may be between different constabularies across the country or even within a single police force. It has previously been show that the police of one division may apply differing strategies to deal with prostitution to neighbouring divisions (Kingston, 2013). Likewise, nationally the police have been known to utilise legislation in different ways (Kingston \& Thomas, 2014). For example, research has shown considerable divergences in how police forces have implemented Engagement and Support Orders across England and Wales, attributed to 
changes in priorities and personnel (Carline \& Scoular, 2015; Scoular \& Carline, 2014). Indeed, the idea that the criminal justice system is characterised by 'justice by geography' is well known (Feld, 1991). We thus argue, that application of the new Injunctions against sex workers and their clients will be inconsistent across England and Wales, varying according to local views, politics and policing discretion.

Injunctions if breached can lead to a maximum penalty of two years imprisonment or an unlimited fine. The length of imprisonment is somewhat shorter than the five years under the previous law, yet soliciting offences have never been punishable by imprisonment. The imposition of a fine however, is nothing new. Kerb-crawling and soliciting charges could lead to a fine of $£ 1000.00$ under previous legislation, which when given to sex workers have been criticised for producing what has been called 'the revolving door' effect, as they continue to sell sex in order to pay off the fine (Phoenix, 2008).

Given that the standard of proof for an Injunction is much lower than for ASBO's, we suggest that the police are likely to prefer the powers under the new Act than soliciting laws. Previous research has documented how some police forces have preferred ASBOs to prosecuting under the soliciting or kerb-crawling laws because the standard of proof required is much lower than in a criminal trial (Hubbard, et al, 2008). As one sex worker suggested, using ASBOS was ‘a sly way of sending girls to prison because you can’t go to prison for prostitution' (interview with woman involved in prostitution, cited in Hester \& Westmarland, 2004:34).

In some instances, in matters of urgency or where evidence of need is provided to the court, interim Injunctions can be made without notice being given to the recipient. Previous cases have demonstrated the surprise and shock of those who have been given interim orders under existing anti-social behaviour law without their knowledge, and there have been instances where six months have lapsed between an interim order being granted and the full court hearing for an ASBO taking place (Panorama, 2005).

The new Injunction will operate in a way similar to ASBOs except that any breach of the Order will not be a criminal offence but rather a breach of a civil injunction dealt with by way of contempt of court; breach would therefore not be an offence that could lead to a criminal record but would still be punishable by up to two years imprisonment and an unlimited fine 
for adults. In addition, the power of arrest can also be added to the Injunction. Any detention in relation to the power of arrest will require the offending person to be brought before the court within 24 hours.

The ASBO could only list activities that the person concerned was prohibited from engaging in; the Injunction permits additional 'requirements' that the person must engage in to be added. This is a move from 'negative' prohibitions to include 'positive' requirements such as attending a course on the effects of alcohol (Anti-social Behaviour, Crime and Policing Act s1 (4) (b)).

Positive requirements could, for example, be applied to sex workers clients, and include the controversial imposition of kerb-crawler re-education programmes, the first of which was piloted in Leeds West Yorkshire and was stopped after just one year (Campbell \& Storr, 2001). The courses can include sexual health advice, awareness raising sessions on the impact of prostitution on local communities and a talk from an ex-prostitute on her experience of violence and abuse. Yet there has been criticism of the ability of such courses to re-educate clients, as it is claimed that they often merely move to other locations to engage in the sex industry (Sanders 2009, Kingston, 2013). Research has also been inconsistent in its evaluation of the success of such schemes with some American research showing a positive effect from such courses (Kennedy et al 2005), whilst others demonstrating no decline in attendees desire to buy sex (Shively et al, 2008).

For sex workers, the requirement to adhere to an Engagement and Support Order (ESO) under s.17 of the Policing and Crime Act 2009, which the CPS (2015) suggest have often been employed prior to the application of an ASBO, has been seen as a positive intervention. The introduction of the orders was part of a wider approach following the Coordinated Prostitution Strategy to 'take a less punitive approach and consider ways that, while enforcing the law, help people in street prostitution to engage with services that could help them begin to change their lives and step out of prostitution' (Alan Campbell then Parliamentary UnderSecretary of State for Crime Reduction cited in Home Office 2010:2, our emphasis). Yet, criticisms of the effectiveness and ability to help sex workers 'moving away from prostitution' (ibid: 2) has been identified by police officers and project workers who have employed ESO’s. As Scoular and Carline’s (2014) research found, for some the requirement to attend three meetings was inadequate and in some instances led to over enforcement as 
some areas criminalised in order to "help" sex workers. ESO supervisors and the police believed that exiting following an ESO was unrealistic as sex workers continued to work. Crucially, the study found that the police took a stricter stance and focused more on the removal of sex workers from the street, with one area issuing ASBOs and CRASBO (Criminal ASBOs see below) upon third summons.

This approach has been identified more broadly across England and Wales, with the CPS (2015) identifying this practice as part of a staged approach to encourage people to exit prostitution. The imposition of an order alongside an ASBO has increased more generally for all types of offences, and is more likely to be imposed following a conviction for a criminal offence (Home Office and Ministry of Justice, 2014a). Yet the exact number of ASBOs issued to sex workers and/or their clients, although the use of them has declined for all types of anti-social behaviour since 2005 (ibid), is not made readily available as the Home Office does not break down its figures according to the types of behaviour and applications to gain such data has been made without success (Ministry of Justice, 2014a). However, evidence explored below demonstrates their continued use against street sex workers.

\section{Part 2 - Criminal Behaviour Orders}

The Criminal Behaviour Order (CBO) will be available following a conviction for any criminal offence and is intended to address the underlying causes of the behaviour through new, positive requirements. An application for an Order can be made in court, at the point of sentencing for the criminal offence. These Orders can be used to prevent the offender from engaging in specified behaviour, or be required to undertake activities identified in the Order. Unlike the civil injunctions, the threshold standard of proof for the court to use when granting this Order is 'beyond reasonable doubt' which aligns with the criminal standard of proof. Breach will be a criminal offence with a maximum penalty of up to five years in prison for adults. It is hoped that this will demonstrate to the offender and the community the seriousness of the breach. Given that sex workers have previously been given custodial sentences for breaching an order (Sanders 2005a), it is likely that this may happen in the future. 
The new Criminal Behaviour Order (CBO) is intended to replace the current ASBO-onconviction (sometimes referred to as the CRASBO). A CBO can be made against someone convicted of a criminal offence if two conditions are met:

The first condition is that the court is satisfied, beyond reasonable doubt that the offender has engaged in behaviour that caused or was likely to cause harassment, alarm or distress to any person.

The second condition is that the court considers that making the order will help in preventing the offender from engaging in such behaviour

(Anti-Social Behaviour, Crime and Policing Act 2014 s22)

A CBO will arguably be more punitive than the CRASBO as it will permit the imposition of 'positive requirements' designed to address the underlying causes of the recipient's antisocial behaviour (such as drug treatment, or anger management courses).

Sanders (2009) has criticised the imposition of ASBOs and CRASBOs as amounting to ‘forced welfarism', because women's agency is ignored. Instead, the compulsory Order 'has no voluntary element because the court decides when a woman is ready to leave the sex industry' (Sanders, 2009:514). This iron fist approach, ignores literature which highlights the complexities of exiting and desistance (Oselin, 2010). As Sanders notes the 'idea that someone can 'exit' an entrenched and complex lifestyle by attending three meetings is entirely in contradiction to the research literature on desistance and change' (Sanders, 2009:514).

For adults a CBO must last for at least two years but could be indefinite. The Criminal Justice Alliance have argued

that both the minimum and maximum duration periods for the CBO are far longer than necessary. A starting point of two years and the potential of an indefinite order will do very little to assist the effectiveness of these Orders. If anything the lengths proposed will act as a disincentive to comply with the Orders. There is no reason why anyone should receive a CBO for an indefinite period of time... (Criminal Justice Alliance 2013:3)

Interim CBOs may be made and variation and discharge can be ordered on application by either the offender or the prosecution. The power to vary an Order includes the power to 
include an additional prohibition or requirement or extend the period for which the CBO has effect.

Liberty has questioned why we need this 'add-on' to a criminal sentence when such requirements are available in other sentences:

'there has been no further explanation as to why CBOs are required in addition to a court's current sentencing powers. Options such as drug treatment and anger management courses are already available as sentences through community orders or by way of conditions imposed when a prisoner is released 'on licence' or 'on probation'. Bringing such requirements under the umbrella of the CBO appears to us to be unnecessary duplication’ (Liberty 2013a:10)

Indeed, given that there are other criminal sanctions available we wonder whether at all, these Orders will be applied for or granted, and if they are what factors will influence the decision to impose this particular Order above other available sanctions. Considerable variations in the use of ASBO, CRASBOs and other civil orders against sex workers has already been highlighted (Scoular et al, 2009; Scoular \& Carline, 2014). Phoenix (2008) found cases of sex workers being prohibited from carrying condoms, and some being banned from areas where drug treatment clinics were located.

\section{Part 3 - Dispersal Powers}

Dispersal Powers will enable a police officer or a Police Community Support Officer (PCSO) to require a person who has committed, or is likely to commit, anti-social behaviour to leave a specified area and not return for up to 48 hours; the power has to be pre-authorised by a police officer of at least inspector rank:

S34 (2) An officer may give such an authorisation only if satisfied on reasonable grounds that the use of those powers in the locality during that period may be necessary for the purpose of removing or reducing the likelihood of-

(a) members of the public in the locality being harassed, alarmed or distressed, or

(b) the occurrence in the locality of crime or disorder.

(Anti-Social Behaviour, Crime and Policing Act 2014 s34 (2)) 
With this authorisation a police officer or PCSO can then 'direct' a person to leave an area for up to 48 hours. The officer must specify the area from which the person is excluded and may specify when and by which route they must leave the area. Failure to comply can lead to three months imprisonment and/or a £2,500 fine. This power will clearly have direct consequences for on-street sex workers as ASBOs have predominantly been used to prevent sex workers soliciting in named areas (Hubbard et al, 2008).

The Act is intended to replace a number of old dispersal powers and to combine elements of the current general dispersal power under section 30 of the Anti-Social Behaviour Act 2003 with elements of the alcohol related dispersal and confiscation powers available under section 27 of the Violent Crime Reduction Act 2006 and the Designated Public Place Orders (DPPO) section 13 in the Criminal Justice and Police Act 2001. Liberty has criticised these existing laws:

The various direction powers currently on the statute book have often proven disastrous in practice. This Draft Bill proposes removing some of the few safeguards that presently exist, widening the availability of dispersal and creating the power to require the surrender of property (Liberty 2013a:11).

The new laws have lowered the rank of authorising officer down from Superintendent to Inspector (although the old dispersal powers under section 27 of the Violent Crime Reduction Act 2006 required no pre-authorisation); the authorising officer has only to think it 'may be necessary' to remove the likelihood of anti-social behaviour from a given locality and no longer has to believe it is a 'persistent problem'. The new laws also allow PCSOs to implement the powers for the first time.

The question of 'locality', which is not defined in the statute, has, in the past, been interpreted by police to include a very wide area, so that people have been excluded from areas as large as 'Greater Manchester' (an area of 493 square miles) or from whole counties like 'South Yorkshire' or 'West Yorkshire' (see Liberty 2013a). There have been instances where ASBO's have been issued to sex workers to prevent them from soliciting anywhere in England and Wales (Hubbard et al, 2008).

This new power will clearly have direct consequences for on-street sex workers and/or their clients, not least because the police have been known to prefer to use powers which are easier 
to employ (Sanders 2005b). Dispersal powers are easier to utilise than Injunctions, because the standard of proof is higher for an Injunction and the case would not have to go through the courts. How many times these powers can be used is not clear, and whether they can be applied once the 48 hours that a person is required to refrain from entering a specified area needs clarification. Thus we suggest that it is likely that these powers will be more commonly used against sex workers than other powers contained in the new Act. Further research will be needed to determine the nature and extent of their usage.

\section{Part 4 - Public Space Protection Order (PSPO).}

The 2014 Act has given powers to the local authorities in the form of the Public Space Protection Order (PSPO). These Orders were implemented from 20 October 2014 and permit the local authority to define an area experiencing behaviour having a 'detrimental effect on the quality of life' that is 'likely to be continuing'; this area then becomes a 'restricted area' where the behaviour in question is 'prohibited'. The Order lasts for a minimum of three years but can be renewed thereafter (Anti-Social Behaviour, Crime and Policing Act 2014 ss59-61).

The local authority are required to publicise that they are proposing to make a PSPO and they must consult with their local Chief Constable and Police and Crime Commissioner and 'whatever community representatives they think appropriate' (Home Office 2014: 48). There is no duty on the local authority to advertise what they are doing in local newspapers and the laws Explanatory Notes are clear that this is all about 'lighter touch consultation requirements to save costs' (Explanatory Notes - para. 186 - available at http://www.legislation.gov.uk/ukpga/2014/12/notes/contents - accessed 12 April 2014). Once the Order has been made the local authority must, however, publicise the existence of the 'restricted area' (The Anti-Social Behaviour, Crime and Policing Act 2014 (Publication of Public Space Protection Orders) Regulations 2014 SI no. 2591).

The PSPO is an Order made by the local authority with again arguably only a minimum of 'checks and balances' in the form of judicial or democratic oversight. Questions could be raised over the meaning of 'the quality of life' and whether or not the behaviour in question has any 'intent' in it. Violations can be dealt with by on the spot fines and this can be outsourced to private companies. Appeals against the PSPO can only be made to the High Court. The campaign group The Manifesto Club believe the PSPO means 'local authorities will possess the most open-ended powers in Europe’ (Manifesto Club 2014: 9). 
The effectiveness of prohibiting street sex workers from entering a particular area has already been called into question. Sanders claimed that:

There is no evidence of their efficiency and effectiveness in terms of reducing visible prostitution. Women who are served with ASBOS are often unaware of the implications of curfews and exclusions zones that state where they can and cannot venture. Hence, ASBOS are often breached because women still need to work or even live in the area they are excluded from (Sanders 2005a:12).

Hester and Westmarland's (2004:34) research suggested only three out of ten female sex workers they interviewed felt that an ASBO would stop them working or make them work elsewhere. Others stated that the threat of an ASBO would not deter them from working in the area, particularly when prostitution was necessary to fund their drug dependency.

Instances, in which sex workers have been excluded or coerced out of an area has not least, highlighted the potential dangers that they can face from moving to unknown and unfamiliar places. The displacement of street based sex work to other areas, as well as the associated increased risks of violence and inability that this causes for harm reduction has been documented (Hubbard \& Sanders, 2003; Kinnell, 2008; Shannon et al, 2008). In some cases, this has had fatal consequences as sex workers decide to work in other locations to escape conviction (Kinnell, 2008).

The UK policies of designating individuals for exclusion from certain areas has thus been called into question, and a strategy of displacement often means that the unwanted behaviour is displaced either temporally, spatially, or functionally. This has been recognised both in the UK and internationally (Hubbard, 1998; Hubbard, 2004; Lowman, 2000). For instance, in the USA where there has in some States been a trend to 'cleanse' cities by designating certain geographic areas out of bounds to certain people; this includes recognising certain 'areas of prostitution'. In one city they issue Stay Out of Areas of Prostitution orders known as SOAP orders:

In Seattle, SOAP orders have been imposed on many of those arrested for or convicted of prostitution-related offenses for the past several decades. According to prosecutors with whom we spoke, most of those charged with prostitution offenses plead guilty and are issued a SOAP order as part of a suspended sentence. In some cases, SOAP orders are imposed as part of a deferred prosecution. One way or the other, nearly all those arrested for prostitution 'get SOAPed' (Beckett and Herbert 2010: 46) 
When Beckett and Herbert asked one probation officer if SOAP orders facilitated rehabilitation, she simply replied 'Hell, no’ (ibid fn.41). As Sanders (2009:6) has suggested those involved 'simply go elsewhere'.

\section{Discussion}

Each time successive Governments have amended the ASB regime, the definition of anti-social behaviour has grown wider, the standard of proof has fallen lower and the punishment for breach has toughened. This arms race must end. We are not convinced that widening the net to open up more kinds of behaviour to formal intervention will actually help to deal with the problem at hand (House of Commons 2013 para 35)

This 'arms race' to lower the thresholds for action against anti-social behaviour, to make applications easier to obtain and to implement has rarely openly stated that each new measure might be used against sex workers. The White Paper Putting Victims First - more effective responses to Anti-social Behaviour (Home Office 2012b), makes no mention of prostitution, red-light areas (1) or sex work and nor does the Home Office document Anti-Social Behaviour, Crime and Policing Act 2014: reform of anti-social behaviour powers - statutory guidance for front-line professionals (Home Office 2014).

Yet as has been shown, ASBO legislation introduced in 1998 was soon utilised to deal with street sex workers and evidence suggests that ASBOs' are still being used to deal with street sex working (CPS, 2015; Scoular \& Carline, 2014). For example, in March 2015, only days before the new powers came into effect, five women were issued with an ASBO in Hull following resident complaints to local police (Williams, 2015). As Alex Feis-Bryce, chief executive of National Ugly Mugs, said 'This is the most regressive and potentially harmful enforcement we have seen in the UK for a while. Issuing Asbos is counter-productive and stigmatising and only serves to entrench existing vulnerabilities’ (cited in ibid).

The use of ASBOs thus clearly continues despite an apparent shift in the regulatory framework surrounding prostitution from an enforcement led approach to a more welfarist 
and multi-agency strategy (Matthews, 2005). However, as Scoular and O’Neill (2007:764) have argued this apparent welfarist approach masks the continued punitiveness of prostitution policy and can be better understood in the context of 'progressive governance' and attempts to 'increase social control under the rhetoric of inclusion'. Street sex workers are encouraged to self-regulate and are individually responsibilized for their actions, rather than the state rectifying the structural inequalities which may lead some sex workers into sex working. Thus, despite recent moves to reconstruct some sex workers as victims it is clear that there is an

on-going hegemonic moral and political regulation of sex workers by continuing to privilege certain forms of citizenship. The neo-liberal agenda bifurcates control by offering social inclusion to those who responsibly exit and ' resume 'normal lifestyles and continued exclusion to those who remain involved in street sex work, and who are constructed and reproduced in law as anti-social. (Scoular \& O’Neill, 2007:765).

Indeed to date, although we have witnessed the introduction of ESO's which seek to "help” street sex workers to exit, they are still liable to a fine of up to $£ 1000.00$ under s.51A of the Sexual Offences Act 2003 and s57 of the Street Offences Act 1959. Furthermore, ASBOs continued to be available, and some police forces have been using them as a 'last resort' when ESOs appear to fail (CPS, 2015). Thus state policy and law, continues to enable practitioners such as the police and CPS, to "help" sex workers or punish them, arguably sending a clear message that street sex workers should be encouraged to exit or face further prosecution.

Yet this approach, to either support or punishment to exit, has not been suggested for indoor sex workers. Within A Coordinated Prostitution Strategy, street sex workers are evidently those to be controlled, whilst there is a lack of focus on indoor sex working (Home Office, 2006). Unsurprisingly, research has shown that the police are generally more tolerant of prostitution that takes place indoors (Kingston, 2013). This public-private divide regarding appropriate sexual activity in certain spaces is nothing new (Hubbard, 2011), and can be traced back to the Wolfenden Report which clearly stated that 'It is not in our view, the function of the law to intervene in the private lives of citizens' (Wolfenden Report 1957:10). 
In recent years, a shift to focus more on penalizing male clients has also emerged and legislation has been introduced to ‘tackle demand’ (Home Office, 2004, 2006, 2008). These laws have made it easier to prosecute men who seek to obtain sexual services from someone on the street and prosecute those who purchase sexual services from someone subject to force, threats or coercion (S.52 of Sexual Offences Act 2003; S.53 of the Sexual Offences Act 2003 as amended by the Policing and Crime Act 2009). The latter offence emerged from concerns over the extent of trafficking and exploitation of women and children into the indoor sex industry. Given the increasing concerns over trafficking and the political drive to 'tackle demand' it is possible that the new ASBO laws may be used to respond to clients.

However, it must also be noted that although legislation enables practitioners to implement the law, it is well-known that the policing of prostitution is inconsistent and varied across England and Wales (Kingston \& Thomas, 2014; Scoular \& Carline, 2014). For example, implementation of the strict liability offence to prosecute clients purchasing sex from exploited or trafficked persons has rarely been enforced (Kingston \& Thomas, 2014). Thus changing forms of governance, which promotes more localized responses to crime (Garland, 2001; Scoular \& O’Neill, 2007), has enabled the police to apply the law uniformly. Although arguably informed by prevailing moral order and public nuisance discourses (Kantola \& Squires, 2004), police discretion and strategic approaches has enabled the implementation of prostitution legislation which is also informed by public complaints (Hubbard, 1998; Jones \& Sagar, 2001 Kingston, 2013), the perceived strategic priority of policing prostitution, police officers attitudes, as well as the availability of resources and personnel (Kingston, 2013; Scoular \& Carline, 2014).

Thus although at the macro, policy and state level, street sex workers are to be either helped or punished, some police forces and/or officers have been known to 'turn a blind eye' to prostitution, appear to tolerate it in certain locations and have established informal working relationships with sex workers; in effect neither helping nor prosecuting sex workers. On the other hand, more localized control has enabled other forces and/officers to take a more punitive approach, and in some instances more punitively towards street sex workers than their clients. What may be referred to as ‘policy refraction' (Freeland, 1986), there may be gaps and distortions in implementation as the new law may be interpreted in different ways by the police. 
In addition, when we examine Home Office statistics on kerb-crawling offences (an offence now repealed by Schedule 8 Part 2 of the Policing and Crime Act 2009 and replaced with the offence of soliciting) it is clear that although a policy drive and legal change may occur its implementation does not always follow through. For example, Home Office statistics from 2005 show that 269 men were cautioned (and one woman) for kerb crawling and in 2006, 332 offences were recorded (CPS, 2012:1). Post-introduction of the Coordinated Prostitution Strategy in 2006 which clearly identified that a key strategy is 'tackling demand', interestingly although there was a peak in the number of prosecutions for kerb-crawling offences between 2007-8 (534) the number of prosecutions fall to their lowest levels in 20112012 (365, CPS, 2012). This is one year after the Policing and Crime Act made the prosecution of 'kerb-crawling' easier, after the removal of the requirement for persistence from the previous offence. Even more interesting is that this 2011-2012 level is the lowest recorded since 1987 when there were 318 convictions (Home Office 2004:92). Further still, statistics taken from the Ministry of Justice (2014b) from their document “Outcomes by Offence” show that since 2009 the number of cautions (758) and prosecutions (711) has fallen steadily to their lowest ever recorded level of prosecutions for kerb-crawling in 2012 (84) and 2013 (85), with the number of cautions also being at their lowest recorded level since records began in 1986.

In contrast, despite claims that a less punitive stance has been taken towards sex workers, in practice it is clear that street sex workers continue to be the focus of police enforcement. The Ministry of Justice (2014b) identified that although there has been a reduction in the number of cautions given for 'prostitute offences', from a peak of 928 in 2010 to the lowest in 2012 of 42 (between the period 2009-2013), the number of prosecutions has not reduced at the same rate and continues to be far higher than for kerb-crawling (664 - 2009; 516 - 2010; 420 2011; 395 - 2012; 424 -2013). In all years during this period, fines were issued more than any other sanction, except in 2011 the year after ESO's were introduced, since then the number of fines given has risen (ibid). Clearly then, street sex workers continue to be the focus of enforcement activities of some police forces, and that enforcement continues to perpetuate the revolving door of fines. Given that sex workers are likely to return to the street to pay off these fines, they may be liable for charges of persistence which has led some forces to impose an ASBO on them (Williams, 2015). 
We thus argue that the new ASB laws, although not explicitly introduced to deal with prostitution will be used to deal with street sex workers and their clients, because as has been shown although less punitive interventions are available, the top-down message is that street sex workers should exit and if they do not they should be punished whilst their clients should always be prosecuted. In addition given that new forms of governance has enabled the police to implement laws in varied ways and are influenced by local forces, we believe the new laws will be used to deal with prostitution, although not in a uniformed way across England and Wales. Yet, crucially we claim that these powers will be used against street sex workers more so than their clients, as they continue to be the focus of police enforcement.

\section{Footnotes}

(1) Defining what actually a 'red-light' area is has been questioned by the courts. In a recent case of a man being told to stay away from 'red-light' areas the Appeal Court noted the inherent difficulties of policing such a requirement 'let alone defining which areas fall within that category' (Richards, $R$ (On the Application Of) $v$ Teesside Magistrates' Court \& Anor (Rev 1) [2015] EWCA Civ 7 at para.36)

\section{References}

APPG (All-Party Parliamentary Group) on Prostitution and the Global Sex Trade (2014) Shifting the Burden: Inquiry to assess the operation of the current legal settlement on prostitution in England and Wales, available at:

http://appgprostitution.files.wordpress.com/2014/03/shifting-the-burden.pdf [accessed 1 March 2014].

Ashworth. A., Gardner, J., von Hirsch, A., Morgan, R., \& Wasik, M. (1998) Neighbouring on the Oppressive: the Government's Anti-social Behaviour proposals, Criminal Justice 16 (1): 7-14.

Associated Press (2013) Zurich opens drive-in 'sex boxes', The Guardian, 26 August, 
BBC News (2010) Time to 'move beyond’ ASBOs says Home Secretary May 28 July, BBC News, available at http://www.bbc.co.uk/news/uk-10784060 [accessed 2 March 2014].

Beckett, K. and Herbert, S. (2010) Banished: the new social control in urban America, Oxford University Press, Oxford.

Bingham, J. (2013) New Asbo plans are assault on basic freedom, says former DPP Lord Macdonald, Daily Telegraph, 8 November,

Burney, E. (1999) Crime and Banishment: Nuisance and Exclusion in Social Housing, Waterside Press, Winchester.

Burney, E. (2005) Making People Behave: anti-social behaviour, politics and policy, Willan Publishing, Cullompton.

Campbell, R. and Storr, M. (2001) Challenging the kerb crawler rehabilitation programme. Feminist Review, 67 (1): 94-108.

Carline, A. \& Scoular, J. (2015) Saving Fallen Women Now? Critical Perspectives on Engagement and Support Orders and their Policy of Forced Welfarism, Social Policy and Society, 14 (1): 103-112.

Criminal Justice Alliance (2013) Evidence to the Home Affairs Committee The draft Antisocial Behaviour Bill: pre-legislative scrutiny 19 February HC 836 iii 2012-13 Ev w45.

Crown Prosecution Service (2012) Violence against Women Strategy and Action Plans, available at: http://www.cps.gov.uk/publications/equality/vaw/vaw_strategy_annex_b.html [accessed 28th April 2014].

Crown Prosecution Service (2015) Prostitution and Exploitation of Prostitution (Legal Guidance), available at:

http://www.cps.gov.uk/legal/p_to_r/prostitution_and_exploitation_of_prostitution/\#a11 [accessed $29^{\text {th }}$ April 2015]. 
Dovkants, K. (2009) Soho brothel to re-open after judge throws out police case, London Evening Standard. 18 February

ECP (English Collective of Prostitutes) (2015) Where the parties stand on sex workers safety and decriminalisation, available at: http://prostitutescollective.net/2015/05/06/parties-standsex-workers-safety-decriminalisation/ [accessed 8 May 2015].

Feld, B.C. (1991) Justice by Geography: Urban, Suburban, and Rural Variations in Juvenile Justice Administration. The Journal of Criminal Law and Criminology, 82 (1): 156-210.

Field, F. (2003) Neighbours from Hell: the politics of behaviour, Politico, London.

Freeland, J. (1986) Australia: the search for a new educational settlement, in: Sharp R. (Ed.) Capitalist Crisis and Schooling: comparative studies in the politics of education, Macmillan, Melbourne, 212-236.

Garland, D. (2001) The Culture of Control: Crime and Social Order in Contemporary Society, Oxford: Oxford University Press.

Hester, M., \& Westmarland, N. (2004) Tackling Street Prostitution: Towards an holistic approach Home Office Research Study 279, Home Office Research, Development and Statistics Directorate, London.

Hewitt, D. (2007) Bovvered? A legal perspective on the ASBO, Journal of Forensic and Legal Medicine, 14 (6): 355-363.

HMIC (HM Inspectorate of Constabulary) (2010) Anti-social behaviour: Stop the rot, available at: http://www.justiceinspectorates.gov.uk/hmic/media/stop-the-rot-20100923.pdf [accessed 3 June 2014].

Home Office (2000) Tackling prostitution: what works? (press release) 18 December, London. 
Home Office (2003) A Guide to Anti-Social Behaviour Orders and Acceptable Behaviour Contracts, Home Office, available at:

http://webarchive.nationalarchives.gov.uk/20100413151441/http:/crimereduction.homeoffice. gov.uk/asbos/asbos9.pdf [accessed 2 March 2014].

Home Office (2004) Paying the Price: a consultation paper on prostitution, July Home Office Communication Directorate, London.

Home Office (2006) A Coordinated Prostitution Strategy and a summary of responses to Paying the Price, London: HMSO.

Home Office (2008) Tackling Demand for Prostitution: A Review, London: HMSO.

Home Office (2010) Guidance on Section 17 Policing and Crime Act 2009: Engagement and Support Orders, available at: http://www.uknswp.org/wpcontent/uploads/GuidanceonSection17PolicingandCrimeAct2009FINAL.pdf [accessed 29 April 2015].

Home Office (2012a) ‘Public input into tackling anti-social behaviour’ (press release) 22 May, London.

Home Office (2012b) Putting Victims First - more effective responses to Anti-social Behaviour, Cm 8367, May, London.

Home Office (2014) Anti-Social Behaviour, Crime and Policing Act 2014: reform of antisocial behaviour powers - statutory guidance for front-line professionals, July, London.

Home Office and Ministry of Justice (2014) Anti-social behaviour order statistics: England and Wales 2013 key findings, available at: https://www.gov.uk/government/publications/antisocial-behaviour-order-statistics-england-and-wales-2013/anti-social-behaviour-orderstatistics-england-and-wales-2013-key-findings, [accessed 29 $9^{\text {th }}$ April 2015].

House of Commons (2013) The draft Anti-social Behaviour Bill: pre-legislative scrutiny Home Affairs Committee - 12th Report of Session 2012-13 HC 836-1. 
House of Lords/House of Commons (2013) Joint Committee on Human Rights Legislative Scrutiny: Anti-social Behaviour, Crime and Policing Bill $4^{\text {th }}$ Report of Session 2013-4 HL Paper 56/HC 713.

House of Lords/House of Commons (2014) Joint Committee on Human Rights Legislative Scrutiny: Anti-social Behaviour, Crime and Policing Bill 9th Report of Session 2013-4 HL Paper 108/HC 951.

Hubbard, P. (1998) Community action and the displacement of street prostitution: Evidence from British cities, Geoforum, 29, 3: 269-286.

Hubbard, P. (2004), Revenge and injustice in the neoliberal city: Uncovering masculinist agendas, Antipode, 36, 4: 665-686.

Hubbard, P. (2011) Cities and Sexualities, London: Routledge.

Hubbard, P., \& Sanders, T. (2003) Making Space for Sex Work: female street prostitution and the production of urban space, International Journal and Regional Research 27 (1): 7387.

Hubbard, P., Matthews, R., \& Scoular, J. (2008). Regulating sex work in the EU: prostitute women and the new spaces of exclusion, Gender, Place and Culture, 15(2), 137-152.

Jones, H. \& Sagar, T. (2001) The Crime and Disorder Act 1998: Prostitution and the AntiSocial Behaviour Order, Criminal Law Review, Nov, 873-85.

Justice (2013) Home Affairs Committee: Written evidence submitted by JUSTICE [ASB 41], House of Commons, available at:

http://www.publications.parliament.uk/pa/cm201213/cmselect/cmhaff/836/836vw36.htm [accessed 2 March 2014].

Kantola, J., \& Squires, J. (2004) Discourses surrounding prostitution policies in the UK, European Journal of Women's Studies, 11(1), 77 - 101. 
Kennedy, M. A., Klein, C., Gorzalka, B. B. \& Yuille, J. C. (2004) Attitude change following a diversion program for men who solicit sex, Journal of Offender Rehabilitation, 40 (1-2): 41-60.

Kingston, S (2004) Street Prostitution: What's the Problem?, Masters Dissertation, The University of Leeds, Unpublished work.

Kingston, S. (2013) Prostitution in the Community: Attitudes, Action and Resistance, London: Routledge.

Kingston, S. \& Thomas, T. (2014) The Police, Sex Work, and Section 14 of the Policing and Crime Act 2009. The Howard Journal of Criminal Justice, 53(3), 255-269.

Kinnell, H. (2008) Violence and Sex Work in Britain, Willan Publishing, Cullompton.

Liberty (2013a) Liberty's Second Reading Briefing on Parts 1 - 6 of the Anti-social Behaviour, Crime and Policing Bill in the House of Commons, June, London.

Liberty (2013b) Liberty’s Report Stage Briefing on the Anti-social Behaviour, Crime and Policing Bill in the House of Commons, October, London.

Lowman, J. (2000), Violence and the Outlaw Status of (Street) Prostitution in Canada. Violence Against Women, 6 (9): 987 - 1011.

Manifesto Club (2014) Briefing on Public Spaces Protection Orders: Response to Statutory Guidance in advance of 20 October enactment of Anti-Social Behaviour, Crime and Policing Act powers, September 2014, available at: http://www.manifestoclub.com/pspomarchbriefing [accessed 15 May 2015].

Matthews, R. (2005) Policing prostitution: Ten years on, British Journal of Criminology, 45, 6: 877-895. 
Ministry of Justice (2014) Freedom of Information Request, available at:

https://www.whatdotheyknow.com/request/189752/response/469641/attach/html/3/1006\%20 13\%20FOI\%2087527\%20Reply.doc.html [accessed 6 May 2015].

Ministry of Justice (2014), Criminal justice statistics quarterly: December 2013 - Outcomes by Offence, available at: https://www.gov.uk/government/statistics/criminal-justice-statisticsquarterly-december-2013 [accessed 6 May 2015].

Oselin, S. S. (2010) Weighing the Consequences of a Deviant Career: Factors Leading to an Exit from Prostitution. Sociological Perspectives, 53, 4: 527-549.

Panorama (2005) ASBOs on Trial, London: BBC1, 20 November.

Phoenix, J. (2008) ASBOs and working women: A new revolving door? In P. Squires (Ed.), ASBO Nation: The Criminalisation of Nuisance. Bristol: The Policy Press, 289-303.

Pitcher, J., Campbell, R., Hubbard, P., O'Neill, M. and Scoular, J. (2006) Living and working in areas of street sex work, Joseph Rowntree Foundation, York

Sagar, T. (2007) Tackling on-street sex work: Anti-social behaviour orders, sex workers and inclusive inter-agency initiatives, Criminology and Criminal Justice, 7 (2): 153-168.

Sanders, T. (2005a) 'The Impact of New UK Legislation on Street-based Sex Workers: AntiSocial Behaviour Orders', Research for Sex Work 8: June: 23-24.

Sanders, T. (2005b), Blinded by morality? Prostitution policy in the UK. Capital and Class, 29 (2): 9-15.

Sanders, T. (2009) UK Sex Work Policy: Eyes Wide Shut to Voluntary and Indoor Sex Work, in Phoenix J (ed.) Regulating Sex for Sale: Prostitution, Policy Reform and the UK, The Policy Press, Bristol, 67-82.

Scoular, J. \& O'Neill, M. (2007) Regulating Prostitution: Social Inclusion, Responsibilization and the Politics of Prostitution Reform. British Journal of Criminology, 47 (5): 764-778. 
Scoular, J., Pitchers, J., Campbell, R., Hubbard, P., and O’Neil, M (2009) 'What’s anti-social about Sex Work?' Governance through the changing representation of prostitutions incivility in Phoenix J (ed.) Regulating Sex for Sale: Prostitution, Policy Reform and the UK, The Policy Press, Bristol: 29-46.

Scoular, J., \& Carline, A. (2014) A critical account of a 'creeping neo-abolitionism':

Regulating prostitution in England and Wales, Criminology and Criminal Justice, 14(5), 608626

Shannon, K., Rusck, M., Shoveller, J., Alexson, D., Gibson, K., \& Tyndall, M. (2008)

Mapping Violence and Policing as an Environmental-Structural barrier to Health Service and Syringe availability among substance-using women in street-level sex work International Journal of Drug Policy 19 (2): 140-147

Shively, M., Jalbert, S. K., Kling, R., Rhodes, W., Finn, P., Flygare, C., Tierney, L., Squires, D., Dyous, C., Wheeler, K. \& Hunt, D. (2008) Final Report on the Evaluation of the First Offender Prostitution Program, Office of Research and Evaluation, National Institute of Justice, Washington. DC.

Taylor, T. (2009) Soho brothel closed by police can re-open, judge rules The Guardian 19 February.

Travis, A. (2014) 'Nuisance and annoyance’ injunctions abandoned after Lords defeat, The Guardian, 23 January.

Williams, M. (2015). Residents praise ban on Hessle Road prostitutes. Hull Daily Mail, 18 March,

Wolfenden Report (1957) Report of the Departmental Committee on Homosexual Offences and Prostitution (Cmnd.247) London: HMSO 